\title{
Blended Learning Model Based on Massive Open Online Courses (MOOCs) Assisted by Augmented Reality (BMA) Model as the Electronic Learning Media in the Pandemic Covid-19
}

\author{
Eko Risdianto', Wachidi², Riyanto3, Alexon4, Irwan Fathurrochman5, Kusen6 \\ DOI: $10.35445 /$ alishlah.v13i1.470
}

\begin{tabular}{l} 
Article Info \\
\hline Keywords: \\
MOOCs \\
E-Learning \\
Augmented Reality \\
Pandemic \\
Covid-19
\end{tabular}

\section{Abstract}

This study aims to analyze educators' responses to implementing the blended learning model based on MOOCs assisted by augmented reality or the so-called BMA model. This BMA model is applied to the learning process using the MOOCs system that has been developed with augmented reality assistance in the midst of the COVID-19 pandemic. To determine the response of prospective educators in the study, data collection techniques were carried out using a questionnaire given to 47 students. This questionnaire consists of 17 question items with 4 Likert scales. The data analysis technique used qualitative, quantitative data analysis. To test the quality of the questionnaire given, data analysis was used using the Rasch model and the winsteps application. Based on the research results, it was found that the instrument data used were valid and reliable. The results of student responses obtained are in very good criteria. This is reinforced by the results of the validity calculation in the rasch analysis which was carried out which stated that 17 items were declared valid and no items were issued. In addition, the value of the calculation of data reliability using the alpha cronbach method with a score of 0.91 is higher than the $\mathrm{r}$ table value for $\alpha=0.050 .2876$. Thus it can be said that the data used is reliable and prospective educators respond very well to the use of this BMA model in the implementation of the learning process through the MOOCs system during the Covid-19 pandemic. This is reinforced by the results of the validity calculation in the rasch analysis which was carried out which stated that 17 items were declared valid and no items were issued. In addition, the value of the calculation of data reliability using the alpha cronbach method with a score of 0.91 is higher than the $r$ table value for $\alpha=0.050 .2876$. Thus it can be said that the data used is reliable and prospective educators respond very well to the use of this BMA model in the implementation of the learning process through the MOOCs

\footnotetext{
${ }^{1}$ Universitas Bengkulu, Bengkulu, Indonesia

Email: eko_risdianto@unib.ac.id

2 Universitas Bengkulu, Bengkulu, Indonesia

Email: wachidi@unib.ac.id

3 Universitas Bengkulu, Bengkulu, Indonesia

Email: riyanto@unib.ac.id

4 Universitas Bengkulu, Bengkulu, Indonesia

Email: alexon@unib.ac.id

5 Institut Agama Islam Negeri (IAIN) Curup, Rejang Lebong, Indonesia

Email: irwan@iaincurup.ac.id

${ }^{6}$ Institut Agama Islam Negeri (IAIN) Curup, Rejang Lebong, Indonesia

Email: kusenpasca1969@gmail.com
} 
system during the Covid-19 pandemic. This is reinforced by the results of the validity calculation in the Rasch analysis, which was carried out, which stated that 17 items were declared valid and no items were issued. In addition, the value of the calculation of data reliability using the alpha cronbach method with a score of 0.91 is higher than the $r$ table value for $a=0.050 .2876$. Thus, the data used is reliable, and prospective educators respond very well to the use of the BMA model in the implementation of the learning process through the MOOCs system during the Covid-19 pandemic.

Kata kunci:

MOOCs

Pembelajaran

Elektronik

Augmented Reality

Pandemi

Covid-19

\begin{abstract}
Abstrak
Penelitian ini bertujuan untuk menganalisis tanggapan pendidik terhadap penerapan model blended learning berbasis MOOC berbantuan augmented reality atau yang disebut dengan model BMA. Model BMA ini diterapkan pada proses pembelajaran menggunakan sistem MOOCs yang dikembangkan dengan bantuan augmented reality di tengah pandemi COVID-19. Untuk mengetahui tanggapan calon pendidik dalam penelitian, teknik pengumpulan data dilakukan dengan menggunakan angket yang diberikan kepada 47 siswa. Kuesioner ini terdiri dari 17 item pertanyaan dengan 4 skala likert. Teknik analisis data menggunakan analisis data kuantitatif dan kualitatif. Untuk menguji kualitas kuesioner yang diberikan, analisis data menggunakan model Rasch dan aplikasi winsteps. Berdasarkan hasil penelitian diketahui bahwa data instrumen yang digunakan valid dan reliabel. Hasil respon siswa yang diperoleh berada pada kriteria sangat baik. Hal tersebut diperkuat dengan hasil perhitungan validitas pada analisis rasch yang dilakukan yaitu sebanyak 17 item dinyatakan valid dan tidak ada item yang diterbitkan. Selain itu nilai perhitungan reliabilitas data menggunakan metode alpha cronbach dengan skor 0,91 lebih tinggi dari nilai $r$ tabel sebesar $\alpha=0,050,2876$. Dengan demikian dapat dikatakan bahwa data yang digunakan dapat diandalkan dan calon pendidik merespon dengan sangat baik penggunaan model BMA ini dalam pelaksanaan proses pembelajaran melalui sistem MOOCs pada saat pandemi Covid-19. Hal tersebut diperkuat dengan hasil perhitungan validitas pada analisis rasch yang dilakukan yaitu sebanyak 17 item dinyatakan valid dan tidak ada item yang diterbitkan. Selain itu nilai perhitungan reliabilitas data menggunakan metode alpha cronbach dengan skor o,91 lebih tinggi dari nilai $r$ tabel sebesar $\alpha=0,050,2876$. Dengan demikian dapat dikatakan bahwa data yang digunakan dapat diandalkan dan calon pendidik merespon dengan sangat baik penggunaan model BMA ini dalam pelaksanaan proses pembelajaran melalui sistem MOOCs pada saat pandemi Covid-19. Hal tersebut diperkuat dengan hasil perhitungan validitas pada analisis rasch yang dilakukan yaitu sebanyak 17 item dinyatakan valid dan tidak ada item yang diterbitkan. Selain itu nilai perhitungan reliabilitas data menggunakan metode alpha cronbach dengan skor 0,91 lebih tinggi dari nilai $r$ tabel sebesar $\alpha=0,05$ 0,2876. Dengan demikian dapat dikatakan bahwa data yang digunakan dapat diandalkan dan calon pendidik merespon dengan sangat baik penggunaan model BMA dalam pelaksanaan proses pembelajaran melalui sistem MOOCs pada saat pandemi Covid-19.
\end{abstract}

\section{INTRODUCTION}

Science and technology continue to evolve, and so is science in education (Sudarsana, 2018). The benefits of implementing information technology in education have been widely felt, such as digital libraries, e-learning, e-books, and others. Seeing the development and learning styles of current students, the majority of whom are generation $\mathrm{Z}$ with characteristics, namely that almost the time spent interacting with things related to digital, tends to want things that are fast and easy to get, for example, students are now indolent to record lecture material As explained by the lecturer, they tend to look for learning materials on the internet. However, the material is obtained through the internet, not all of them are of high quality. Therefore an internet-based learning platform is needed to adapt to the times (Suyasa et al., 2017). Digital technology is the thing that most influences the education system in the world today. This is due to the aspects of effectiveness, efficiency, and 
attractiveness offered by digital technology-based learning (Putrawangsa \& Hasanah, 2018). However, access to educational sites is still lacking. This is what educators need to address immediately by directing their students to use the internet more in the realm of education (Yodha et al., 2019).

Currently, the world is experiencing challenges, especially during the current Covid 19 pandemic. Learning that was previously done offline is now done online. Online learning that is appropriate to do by looking at the condition of the internet network infrastructure in Indonesia is blended learning. To carry out blended learning in the learning process, a system is needed that is able to adapt to user needs both online and offline.

One of the impacts of rapid technological advances is online courses called MOOCs (Risdianto et al., 2021). This learning platform can be accessed openly to provide education that can be accessed widely and on a large scale (Rafiq et al., 2019). Massive Open Online Courses (MOOCs) first appeared on the higher education horizon in 2008, when it coincided with the launch of Connectivism and Connective Knowledge (CCKo8) facilitated by George Siemens and Stephen Downes (Emigawaty, 2017). The feel of MOOCs has expanded online learning to a large scale around the world, presenting new opportunities and new challenges (Praherdhiono et al., 2018). MOOCs exist as a new model of education and learning, which uses the internet to deliver course materials in prestigious universities and educational institutions globally, creating a kind of revolution. These people join each other to take continuous courses (Husna, 2019). Teachers are now encouraged to be proficient in e-learning literacy such as MOOCs so that science in the 21st century can be applied and utilized in the teaching and learning process (Ismail et al., 2018). Similar research on learning with MOOCs has also been conducted by Ismail et al. (2018). The results showed that learning with MOOC was very good and could increase student interest and motivation. Another study was also conducted by Eldwita et al. (2019). This study concluded that learning with MOOCs was adequate for use in physics learning (Busri et al., 2019). The two previous studies were in line with the research results I got, namely, learning with MOOCs received good responses from students (Fathurrochman et al., 2021).

Blended learning is a term that comes from English which consists of two syllables, namely blended and learning. Blended learning is a combination of face-to-face and online learning (Khoiroh et al., 2017). From several existing studies, it is stated that if the blended learning model is applied to the learning process, it will be more effective with the transition of students to a higher level in acquiring knowledge and developing skills (Oktaria et al., 2018). The mixed learning approach helps create a shared understanding of important concepts with the learning culture and provides opportunities to reinforce them in dynamic classroom settings (Fandianta et al., 2013). Blended learning is developed because of the weaknesses that arise in face-to-face learning and e-learning. Apart from being developed because of the emergence of the weaknesses of the two lessons, blended learning was developed because of the advantages of face-to-face learning and e-learning (Wardani et al., 2018).

The purpose of the blended learning model is to get the best learning by combining the various advantages of each component of the conventional method and the online part (Priono et al., 2018). The Blended Learning method has become a trend and is widely used in leading universities globally (Usman, 2018). Graham (2006), in the handbook of blended learning, global perspectives, local design, says that blended learning has the following advantages: (1) Flexibility, meaning that students can contribute to the discussion at the time and place they individually choose. (2) Participation, meaning that all students can participate in the learning process because they can arrange the time and place to participate. (3) Lessons have more time to be more careful in arguing and reflect more deeply on their views and opinions (Prayitno \& Masduki, 2017).

One of the uses of technology in education is the use of augmented reality technology in learning. Augmented reality (AR) is a technology that visually adds to the real-world environment by projecting computer-generated information into the eye(Siahaan et al., 2019). Augmented Reality or abbreviated (AR), is an integral part of future education. AR technology is believed to change and 
become an increasing trend in learning in the future (Risdianto, 2019). The way AR works in adding virtual objects to the natural environment is as follows: 1) The actual world image is taken from the camera; 2) Start the tracking process to get the virtual object rendering position; 3) The virtual object is inserted into the real image based on the results (Pragestu et al., 2015). Augmented reality technology can be used without using an internet connection.

The BMA model or the blended learning model based on MOOCs assisted by augmented reality is a model that the previous authors have developed to facilitate mixed learning using the augmented reality-assisted MOOCs system. Augmented reality technology is used to assist the learning process for areas that have poor internet infrastructure. The implementation of this BMA model has been carried out on 47 students who take ICT learning media courses. The following are the stages of the BMA model implementation.

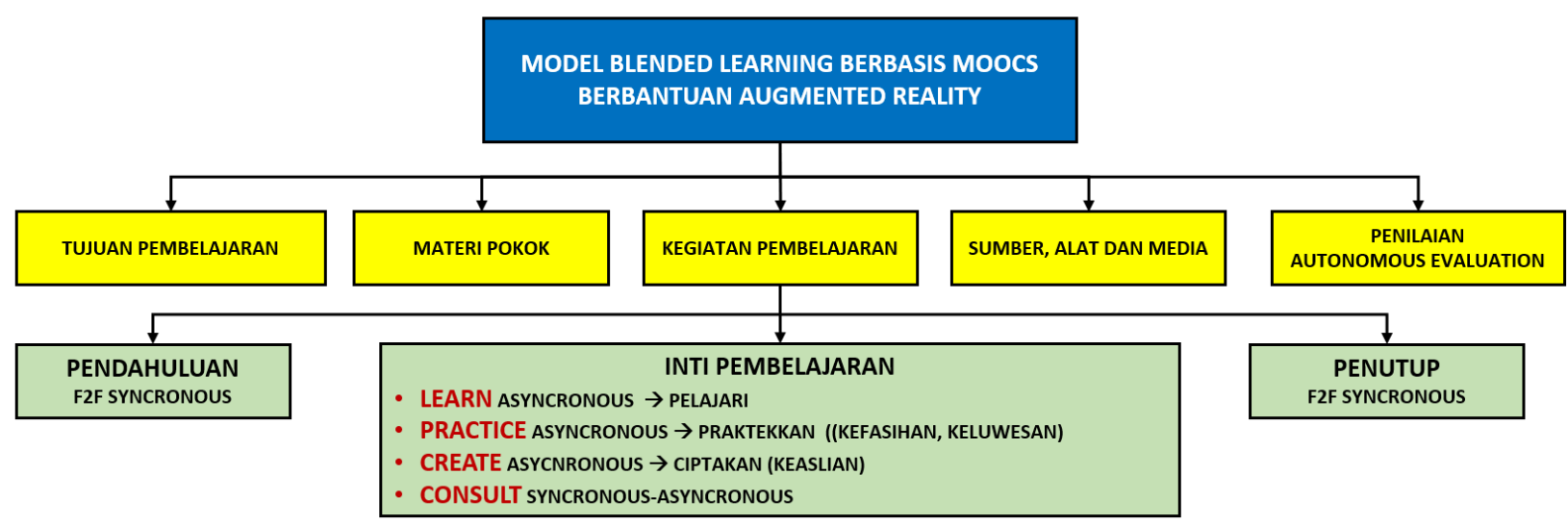

Figure 1. The BMA Model

To find out the quality of the BMA model that has been given, data is needed about the responses of students who have used this BMA model in the learning process. So from the description above, it is necessary to analyze the student's response to the implementation of the BMA model that has been given and test the quality of the response questionnaire used so that the results given are valid and reliable.

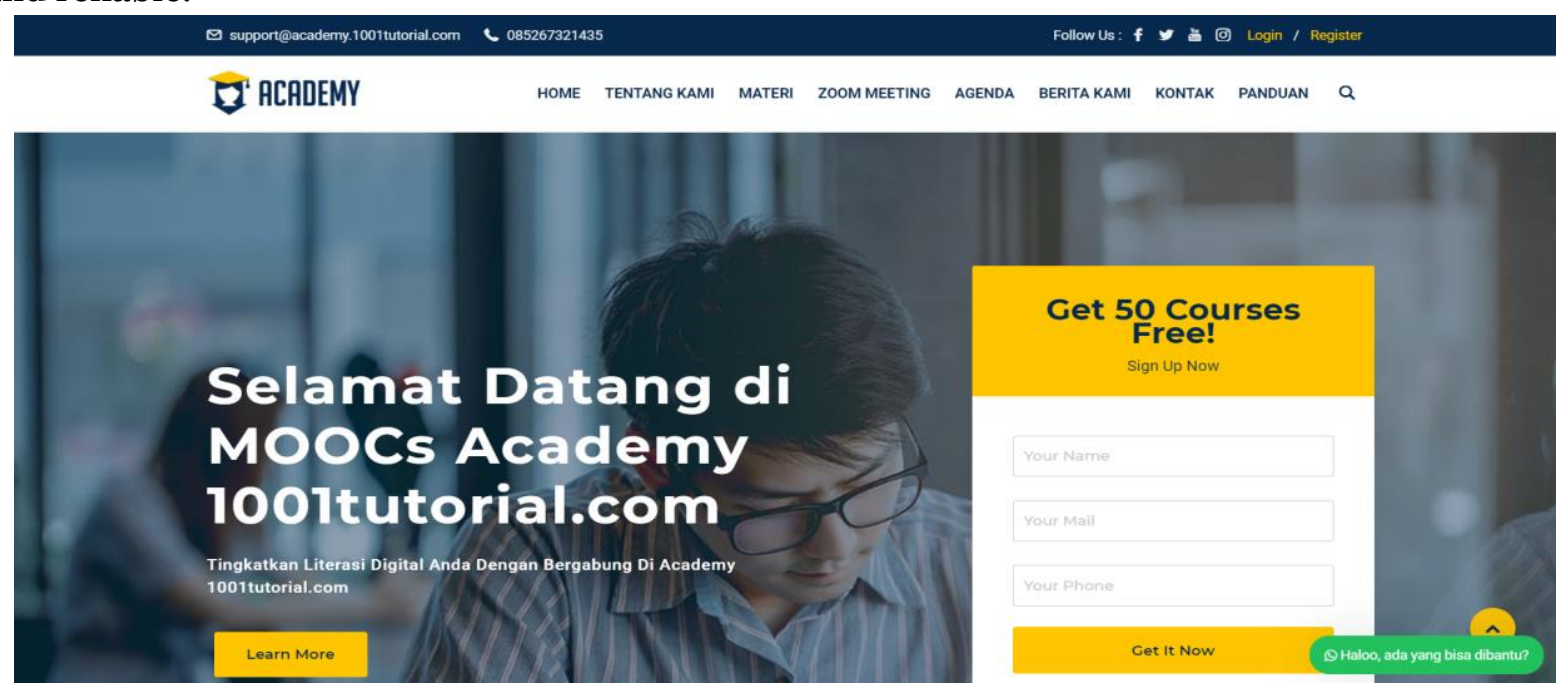

Figure 2. Developed MOOCs System 


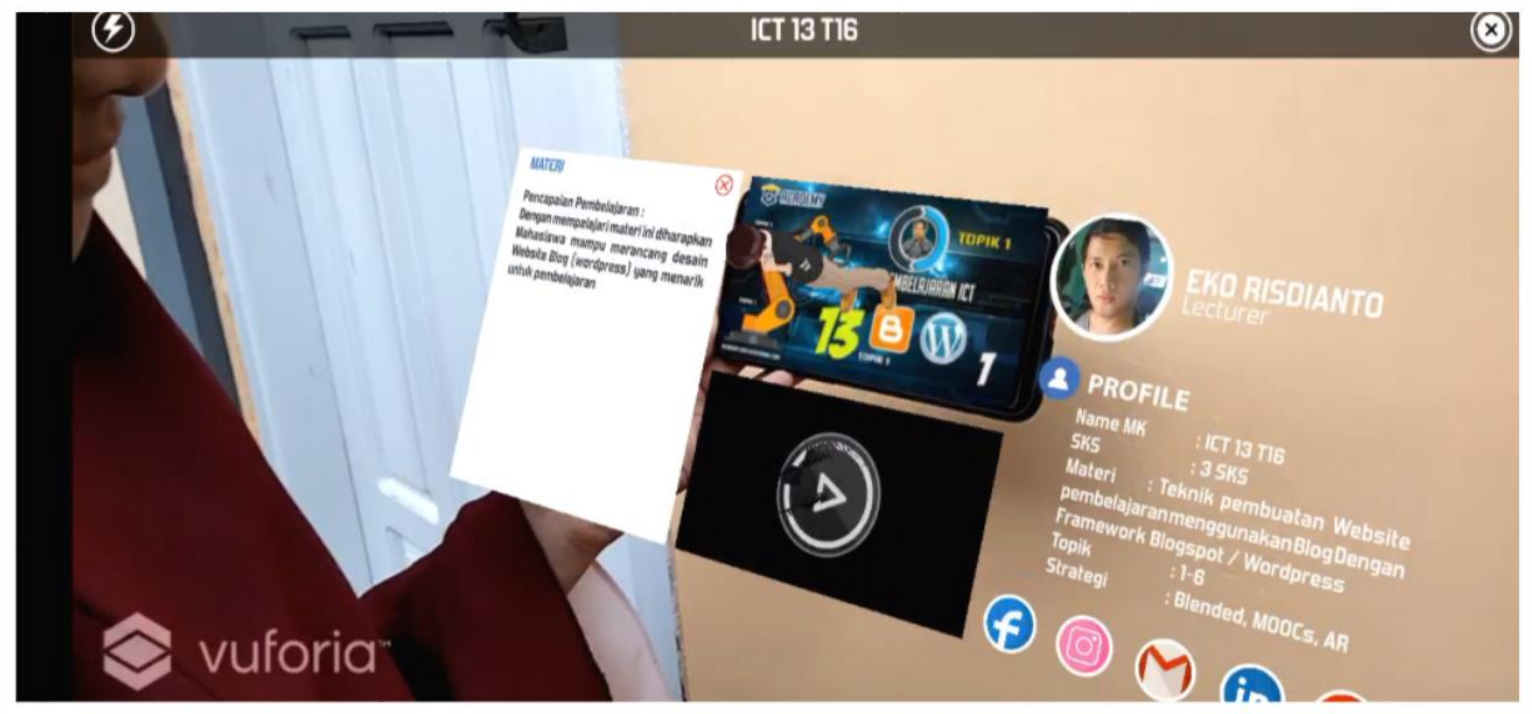

Figure 3. Examples of Augmented Reality Technology Used

\section{METHOD}

This research is part of a research and development $(\mathrm{RnD})$ series carried out using the 10 steps of Borg and Gall's development, namely the Dissemination and Implementation stage.

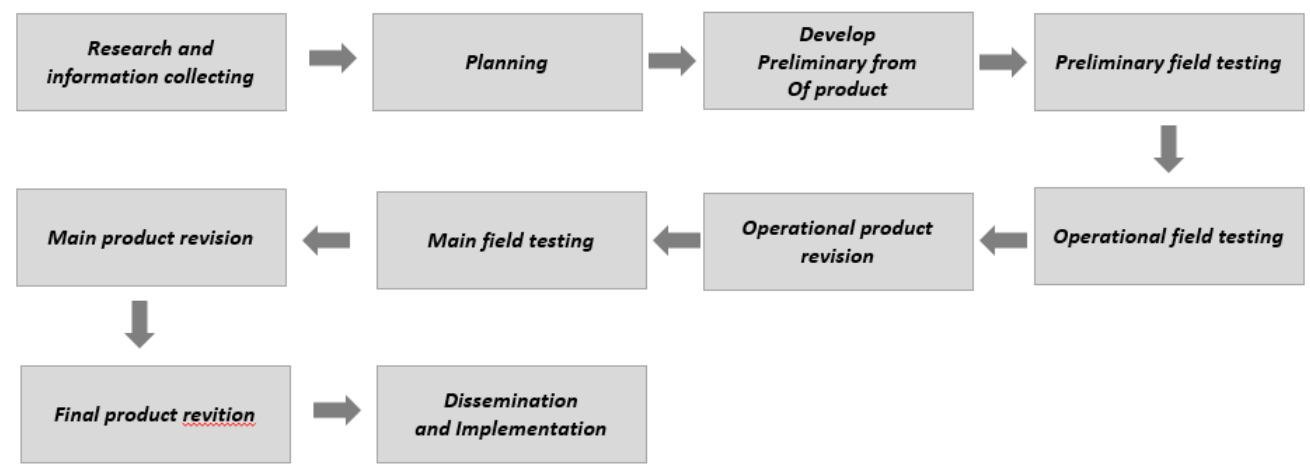

Figure 4. 1o Development Steps for Borg and Gall

The data sample used in this study were 47 prospective educators in the PMIPA Department of Bengkulu University who had participated in the learning process using the blended learning model based on MOOCs assisted by the augmented reality BMA model. The material used in this study is a student response questionnaire sheet consisting of 17 question items.

The questionnaire data was tested for validity and reliability. The validity of the data can be seen from the resulting Va, which is then adjusted according to the following interpretations.

To find out the amount of Va, we can use the formula

$$
V_{a}=\frac{\sum_{1}^{3} A_{i}}{n}
$$

Where $\Sigma_{1}^{3} A_{i}$ is the total acquisition score while $\mathrm{n}$ is the number of items.

The Va value obtained is then adjusted to the following validity interpretation table. 
Table 1. Interpretation of Validity

\begin{tabular}{ccc}
\hline Not & Size & Criteria \\
\hline 1 & $1 \leq V_{a}<2$ & Invalid \\
2 & $2 \leq V_{a}<3$ & Less Valid \\
3 & $3 \leq V_{a}<4$ & Valid \\
\hline
\end{tabular}

To find out the reliability of our data, we use a formula

$$
\text { R eliabilitas }=\left(\frac{k}{k-1}\right)\left(1-\frac{\Sigma \sigma_{n}}{\sigma_{t}}\right)
$$

Where $\mathrm{k}$ is the number of items, ${ }^{\Sigma} \sigma_{n}$ is the number of grain variants and $\sigma_{t}$ is the total variant Data is said to be reliable if rcount $>$ rtable

Data analysis was performed using the Rasch Model using the Winstep application to confirm the results and determine the quality of the questionnaire.

\section{FINDING AND DISCUSSION}

Student responses to implementing the BMA model in the MOOCs system as a learning media assisted by augmented reality were carried out using a questionnaire data collection technique with 4 Likert scales. Questionnaire analysis was conducted to determine student responses to MOOCs as assisted e-learning augmented reality media. Forty-seven respondents filled in the questionnaire for this need with 17 items. The assessment uses a Likert scale with a maximum score of 4 and a minimum questionnaire item 1 . Following are the results of the validity calculation

$$
V_{a}=\frac{\Sigma_{1}^{3} A_{i}}{n}=\frac{56,8298}{17}=3,3429
$$

Because the value of $\mathrm{Va}=3.3429$, based on the validity interpretation table (table 1 ), the data we use is valid.

For data reliability, we can see the following calculations:

$$
\begin{aligned}
& \text { Re liabilitas }=\left(\frac{k}{k-1}\right)\left(1-\frac{\Sigma \sigma_{n}}{\sigma_{t}}\right) \\
& \text { Re liabilitas }=\left(\frac{17}{17-1}\right)\left(1-\frac{4,73}{35,20}\right) \\
& \text { Re liabilitas }=(1,06)(0,86) \\
& \text { Re liabilitas }=0,91
\end{aligned}
$$

The results we get are said to be rcount. Then we have to look at $r$ table or simple correlation coefficient table for $\mathrm{df}=45$. In table $\mathrm{r}, \mathrm{r}$ table is 0.2876 . Because rcount is greater, namely 0.91 , than rtable, which is 0.2876 , the data is said to be reliable. 
To confirm the results and determine the quality of the questionnaire given, data analysis was performed using the Rasch Model using Winstep. From the data obtained using the Winstep Variable Maps data (Wright map), the results can be seen in the image below:

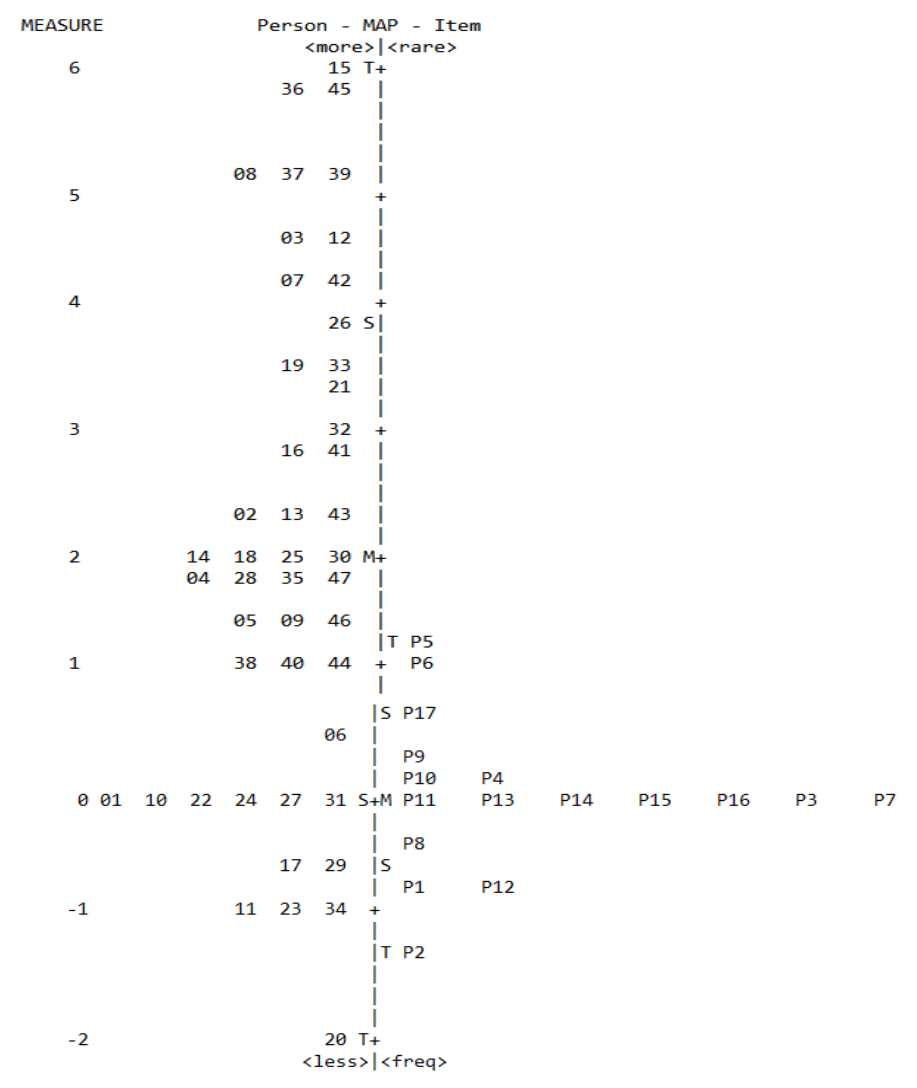

\section{Figure 5. Test Variable Maps}

In figure 3, the Variable Map Test consists of measures (showing the logit scale). On the left side is the distribution of the subject (respondent) ability, while on the right side is the distribution of items (questions). From this map, it can be seen that, in general, the questions on the test are more complicated than the respondent's ability. On the map on the right, 17 questions have validity levels of varying difficulty starting from $\mathrm{P}_{5}$ tang, the most challenging questionnaire item, to $\mathrm{P}_{2}$, which has the lowest response item. From the questionnaire data, the question with the lowest difficulty level is question no. 2 (P2), with the average logit item is -1.35 . The highest ability value is item number 5 ( $\mathrm{P}_{5}$ ), which is in the top position with an average logit item of 1.24.

This shows a good thing because each question given can provide information regarding the respondent's ability being tested. If we look at the distribution of the response items, they are diverse and grouped. Next, we will analyze the MST distance found on the Wright map above. It can be seen that the ability of the respondents is only slightly wider than the distribution found in the difficulty level of the response items. In the context of the level of difficulty in the response items, the item responses to the questions have not too much diversity, and the respondents' ability is not much different. This is according to if there is a wider distribution of person abilities than the distribution of items. It can be concluded that the level of person (respondent) ability is different.

On the left-right map, 47 students have various ability scores and also in groups. From the data above, it can be seen that almost all respondents have a high level of ability in answering the questionnaire items given, on the map on the left with 47 respondents who have the highest level of ability with code no 15, by getting the maximum value that can be obtained. It has a logit average (+7.12 logit). From the person variable map data, it can be seen that the respondent/participant who 
has the highest score of ability to answer questions and has the highest ability is 35 respondents, and for the respondent who has the lowest ability is respondent no. 04 and 01. From the variable map data, it can be seen that even though the respondent is no. 20 has the lowest ability but can still answer the most challenging response items, namely No.2 (P2). This means that almost all respondents agreed with all the questionnaire item responses given to the participants and showed that the questionnaire data were valid and reliable.

When comparing the average logit item with the logit person, it can be seen that the logit person is larger $(+2.20$ logit). This indicates that the overall ability is only slightly higher than the question difficulty. If we compare the distance between the MST on the Wright map above, it can be seen that the distribution for student ability (on the left) is wider than the distribution on the difficulty level of the item (on the right). In the context of the difficulty level of the questions, this shows that the items of diversity are not very far apart; However, from the aspect of student ability, it can be seen that the ability distance is vast (Untary et al., 2020).

To find out the level of difficulty of the questions on a more precise logit scale, using the item size, results are obtained as in the table below:

Item STATISTICS: MEASURE ORDER

\begin{tabular}{|c|c|c|c|c|c|c|c|c|c|c|c|c|c|}
\hline \multirow{2}{*}{$\begin{array}{l}\text { | ENTRY } \\
\text { |NUMBER }\end{array}$} & \multirow{2}{*}{$\begin{array}{l}\text { TOTAL } \\
\text { SCORE }\end{array}$} & \multirow{2}{*}{$\begin{array}{l}\text { TOTAL } \\
\text { COUNT }\end{array}$} & \multirow[b]{2}{*}{ MEASURE } & \multirow{2}{*}{$\begin{array}{l}\text { MODELI } \\
\text { S.E. }\end{array}$} & \multicolumn{2}{|c|}{ INFIT } & \multicolumn{2}{|c|}{ OUTFIT } & \multicolumn{2}{|c|}{ |PTMEASUR-AL| } & \multirow{2}{*}{\multicolumn{2}{|c|}{ EXACT MATCH| }} & \multirow[b]{2}{*}{ Item } \\
\hline & & & & & MNSQ & ZSTD & MNSQ & ZSTD & |CORR. & EXP. I & OBS\% & & \\
\hline $\begin{array}{c}-. \\
5\end{array}$ & 148 & 47 & 1.24 & .36 & 1.19 & .85 & |1.21 & $\begin{array}{r}.78 \\
.78\end{array}$ & .59 & $\begin{array}{l}---+ \\
.65\end{array}$ & 73.9 & 78.1 & P5 \\
\hline 6 & 149 & 47 & 1.10 & .37 & .74 & -1.15 & .80 & -.65 & .59 & .65 & 84.8 & 78.4 & P6 \\
\hline 17 & 152 & 47 & .70 & $.37 \mid$ & 1.45 & 1.76 & 1.44 & 1.43 & .48 & $.66 \mid$ & 78.3 & $78.8 \mid$ & P17 \\
\hline 9 & 155 & 47 & .29 & $.37 \mid$ & .79 & -.87 & .86 & -.38 & .63 & $.66 \mid$ & 87.0 & $79.1 \mid$ & P9 \\
\hline 4 & 156 & 47 & .15 & $.37 \mid$ & .92 & -.29 & .78 & $-.67 \mid$ & .61 & $.66 \mid$ & 76.1 & $79.0 \mid$ & P4 \\
\hline 10 & 156 & 47 & .15 & $.37 \mid$ & 1.03 & .19 & 1.07 & .31 & .68 & $.66 \mid$ & 76.1 & 79.0 & P10 \\
\hline 13 & 157 & 47 & .02 & $.37 \mid$ & .73 & -1.23 & .61 & -1.39 & .75 & $.66 \mid$ & 80.4 & 78.9 & P13 \\
\hline 14 & 157 & 47 & .02 & .37 & .72 & -1.29 & .64 & -1.23 & .78 & $.66 \mid$ & 84.8 & $78.9 \mid$ & P14 \\
\hline 16 & 157 & 47 & .02 & $.37 \mid$ & 1.03 & .22 & .83 & -.46 & .68 & $.66 \mid$ & 84.8 & $78.9 \mid$ & P16 \\
\hline 3 & 158 & 47 & -.12 & $.37 \mid$ & 1.01 & .13 & .79 & $-.63 \mid$ & .70 & $.66 \mid$ & 82.6 & $78.7 \mid$ & P3 \\
\hline 7 & 158 & 47 & -.12 & $.37 \mid$ & 1.28 & 1.23 & 1.68 & 1.91 & .61 & $.66 \mid$ & 69.6 & 78.7| & P7 \\
\hline 11 & 158 & 47 & -.12 & $.37 \mid$ & .91 & -.33 & .96 & -.04 & .68 & $.66 \mid$ & 82.6 & $78.7 \mid$ & P11 \\
\hline 15 & 158 & 47 & -.12 & $.37 \mid$ & 1.26 & 1.15 & 1.27 & .89 & .69 & $.66 \mid$ & 73.9 & $78.7 \mid$ & P15 \\
\hline 8 & 160 & 47 & -.39 & $.37 \mid$ & .58 & -2.22 & .51 & -1.72 & .75 & $.65 \mid$ & 91.3 & $78.3 \mid$ & P8 \\
\hline 1 & 162 & 47 & -.67 & $.37 \mid$ & 1.18 & .89 & 1.42 & 1.18 & .59 & $.65 \mid$ & 71.7 & $77.4 \mid$ & P1 \\
\hline 12 & 163 & 47 & -.80 & $.37 \mid$ & .89 & -.47 & .86 & -.29 & .69 & $.65 \mid$ & 87.0 & $77.2 \mid$ & P12 \\
\hline 2 & 167 & 47 & -1.35 & $.37 \mid$ & .93 & -.27 & .78 & -.40 & .64 & $.63 \mid$ & 78.3 & $77.5 \mid$ & P2 \\
\hline MEAN & 157.1 & 47.0 & .00 & .37| & .98 & -.1 & .97 & $-.1 \mid$ & & & 80.2 & $78.5 \mid$ & \\
\hline P.SD & 4.5 & .0 & .62 & .00 & .23 & 1.0 & .32 & 1.0 & & & 5.9 & $.6 \mid$ & \\
\hline
\end{tabular}

\section{Figure 4. Response Item Analysis Table}

Based on the results of the student response analysis using the winsteps program in Figure 4 , it can be seen that the total number of filled responses is 47 responses. This indicates that all respondents answered all the items given. From the picture above, the item column shows the level of difficulty of the item shown in the measure column, namely from the questionnaire item, the most challenging response is $\mathrm{P}_{5}$ and the easiest is $\mathrm{P}_{2}$. The difficulty level of the questions makes it easy for us to identify which questions are complicated and easy.

Item analysis and Rasch modeling analysis, when combined, will provide complementary data. Iteman's analysis analyzes the question while the Rasch modeling analysis can analyze the relationship between the questions and the respondent. In the iteman analysis, respondents with the same score are considered to have the same ability. In contrast, in Rasch modeling, respondents with the same score can be seen as their level of knowledge. In Rasch analysis, the model can find out the person fit. Person fit determination also uses the same criteria as fit items (Nuryanti et al., 2018). 
Winstep software is a computational tool in the Rasch model to analyze the scores generated from the test instrument to know the MNSQ Outfit, ZSTD Outfit, Point Measure Correlation, Item reliability, and CronbachAlpha. MNSQ clothing is useful for seeing the suitability of data with the model used. The average value of the squares expected is 1 (one). If the mean-square infit value is more significant than one, the variation of the instrument is more significant than the predictions made by the Rasch model. If the infit value is less than 1 , then the variation in the instrument is less when compared to the predictions made by the Rasch model (Wahyuningsih, 2020).

To determine the suitability of the question (item fit), it is according to the ideal measurement model. Select table 10. Items to order. The table below shows that the item suitability indicators for all question items are the clothing means box $(0.5<\mathrm{MNSQ}>1.5)$, the standard $\mathrm{Z}$ outfit $(-2.0<\mathrm{ZSTD}$ $<+2.0$ ), and the point measurement correlation. . (0.4<Pt Measure corr <0.85), this does not indicate a problem. All the questions given can be understood well by all respondents. There are no questions that are misconceptions (Sumintono, 2015).

\begin{tabular}{|c|c|c|c|c|c|c|c|c|c|c|c|c|}
\hline ENTRY & TOTAL & TOTAL & & MODEL | & & NFIT & OUT & FFIT |PTMEAS & UR-AL | & EXACT & МATCH | & \\
\hline NUMBER & SCORE & COUNT & MEASURE & S.E. I & MNSQ & ZSTD| & |MNSQ & ZSTD|CORR. & EXP. I & OBS\% & EXP\% & Item \\
\hline 7 & 158 & 47 & -.12 & $.37 \mid$ & 1.28 & $1.23 \mid$ & |1.68 & $1.91 \mid A .61$ & $.66 \mid$ & 69.6 & 78.기 & P7 \\
\hline 17 & 152 & 47 & .70 & .37| & 1.45 & 1.76 & |1.44 & $1.43 \mid \mathrm{B} .48$ & $.66 \mid$ & 78.3 & $78.8 \mid$ & P17 \\
\hline 1 & 162 & 47 & -.67 & $.37 \mid$ & 1.18 & .89 & 1.42 & $1.18 \mid \mathrm{C} .59$ & .65 & 71.7 & $77.4 \mid$ & P1 \\
\hline 15 & 158 & 47 & -.12 & $.37 \mid$ & 1.26 & 1.15 & |1.27 & $.89 \mid \mathrm{D} .69$ & $.66 \mid$ & 73.9 & $78.7 \mid$ & P15 \\
\hline 5 & 148 & 47 & 1.24 & $.36 \mid$ & 1.19 & $.85 \mid$ & |1.21 | | | | | & $.78 \mid \mathrm{E} .59$ & .65 & 73.9 & $78.1 \mid$ & P5 \\
\hline 10 & 156 & 47 & .15 & $.37 \mid$ & 1.03 & .19| & 1.07 & $.31 \mid F .68$ & .66 & 76.1 & 79.01 & P10 \\
\hline 16 & 157 & 47 & .02 & $.37 \mid$ & 1.03 & .22 & | .83 & $-.46 \mid G .68$ & $.66 \mid$ & 84.8 & $78.9 \mid$ & P16 \\
\hline 3 & 158 & 47 & -.12 & $.37 \mid$ & 1.01 & |13| & | .79 & $-.63 \mid \mathrm{H} .70$ & $.66 \mid$ & 82.6 & 78.7미 & P3 \\
\hline 11 & 158 & 47 & -.12 & $.37 \mid$ & .91 & $-.33 \mid$ & | .96 & $-.04 \mid \mathrm{I} \quad .68$ & $.66 \mid$ & 82.6 & 78.7 | & P11 \\
\hline 2 & 167 & 47 & -1.35 & $.37 \mid$ & .93 & $-.27 \mid$ & | .78 & $-.40 \mid \mathrm{h} .64$ & $.63 \mid$ & 78.3 & $77.5 \mid$ & P2 \\
\hline 4 & 156 & 47 & .15 & $.37 \mid$ & .92 & $-.29 \mid$ & | .78 & $-.67 \mid \mathrm{g} \quad .61$ & $.66 \mid$ & 76.1 & 79.01 & P4 \\
\hline 12 & 163 & 47 & -.80 & $.37 \mid$ & .89 & $-.47 \mid$ & .86 & $-.29 \mid f .69$ & .65 & 87.0 & $77.2 \mid$ & P12 \\
\hline 9 & 155 & 47 & .29 & $.37 \mid$ & .79 & $-.87 \mid$ & .86 & $-.38 \mid \mathrm{e} .63$ & .66 & 87.0 & $79.1 \mid$ & P9 \\
\hline 6 & 149 & 47 & 1.10 & .37| & .74 & -1.15 & | .80 & $-.65 \mid d \quad .59$ & .65 & 84.8 & $78.4 \mid$ & P6 \\
\hline 13 & 157 & 47 & .02 & $.37 \mid$ & .73 & $-1.23 \mid$ & | .61 & $-1.39 \mid c .75$ & $.66 \mid$ & 80.4 & $78.9 \mid$ & P13 \\
\hline 14 & 157 & 47 & .02 & $.37 \mid$ & .72 & $-1.29 \mid$ & | .64 & $-1.23 \mid \mathrm{b} .78$ & $.66 \mid$ & 84.8 & $78.9 \mid$ & P14 \\
\hline 8 & 160 & 47 & -.39 & $.37 \mid$ & .58 & -2.22 & | .51 & $-1.72 \mid a \quad .75$ & .65 & 91.3 & $78.3 \mid$ & P8 \\
\hline MEAN & 157.1 & 47.0 & .00 & $.37 \mid$ & | .98 & $-.1 \mid$ & | .97 & $-.1 \mid$ & & 80.2 & 78.5 & \\
\hline P.SD & 4.5 & .0 & .62 & $.00 \mid$ & .23 & 1.0 이 & | .32 & 1.0 & & 5.9 & $.6 \mid$ & \\
\hline
\end{tabular}

Figure 5. Table of Compliance Level Questions

Based on the student response analysis results with the winsteps program in Figure 5,17 misfit items and 17 fit items were obtained. Thus, obtained 17 items. From the data above, it can be seen from all items for the value of Outfit Mean Square item no. 7 has an MNSQ of 1.68, for a ZSTD of 1.91 and or equal to 0.61 , all of which are under predetermined criteria. If there is 1 criterion that still meets the required criteria, then the item does not need to be replaced or maintained.

The following is the suitability curve of response item no. 5 in the curve image below. It can be seen that 2 responses are outside the boundary of the Outfit trust space. This can also be shown by the ICC graph as shown below: 
5. P5

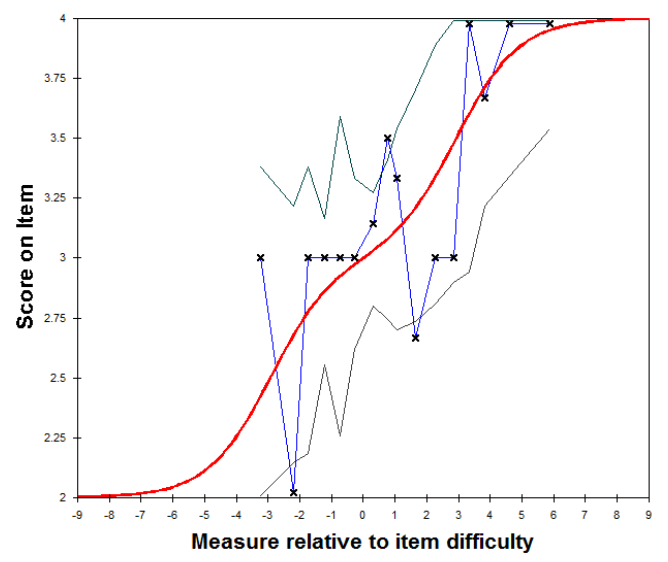

Figure 6. ICC Expected Score Graph

To analyze respondents who filled out the questionnaire items, we chose the 17 Person Measure table. The ability data will be displayed sequentially from highest to lowest, as follows:

Person STATISTICS: MEASURE ORDER

\begin{tabular}{|c|c|c|c|c|c|c|c|c|c|c|c|c|c|}
\hline $\begin{array}{l}\text { ENTRY } \\
\text { NUMBER }\end{array}$ & $\begin{array}{l}\text { TOTAL } \\
\text { SCORE }\end{array}$ & $\begin{array}{l}\text { TOTAL } \\
\text { COUNT }\end{array}$ & MEASURE & $\begin{array}{l}\text { MODELI } \\
\text { S.E. }\end{array}$ & $\mid \begin{array}{r}\text { IN } \\
\text { MNSOQ }\end{array}$ & $\begin{array}{l}\text { IFIT } \\
\text { ZSTDI }\end{array}$ & $\mid \begin{array}{r}\text { OUT } \\
\text { MNSQ }\end{array}$ & $\begin{array}{l}\text { TFIT } \\
\text { ZSTD }\end{array}$ & $\begin{array}{l}\text { PTMEAS } \\
\text { CORR . }\end{array}$ & $\begin{array}{r}\text { UR-AL I } \\
\text { EXP. I }\end{array}$ & $\begin{array}{r}\text { EXACT } \\
\text { OBS\% }\end{array}$ & $\begin{array}{r}\text { MATCH | } \\
\text { EXP\%| }\end{array}$ & \\
\hline & & & & & & & & & & & & & \\
\hline $\begin{array}{l}15 \\
36\end{array}$ & 67 & 17 & 5.85 & 1.84 & Maxi & MUM mi & & & .00 & & & & 15 \\
\hline & 67 & & 3.03 & 1.04 & 1.08 & .38 & 11.31 & $.62 \mid$ & -.05 & .15 & 94.1 & 94.1 & 36 \\
\hline & 66 & 17 & 3.85 & 1.04 & 1.03 & .331 & .89 & .26 & .12 & .15 & 94.1 & 94.1 & 45 \\
\hline & 00 & 17 & 5.07 & .77 & .80 & $-.20 \mid$ & .50 & -.63 & .57 & .20 & 88.2 & 88.2 & 08 \\
\hline 39 & 66 & 17 & 5.07 & .77 & 1.15 & .45 & 1.55 & .90 & -.15 & .20 & 88.2 & 88.2 & 37 \\
\hline 3 & 66 & 17 & 5.07 & .77 & 11.14 & .43 & 11.27 & .58 & -.07 & .20 & 88.2 & 88.21 & 39 \\
\hline $12^{3}$ & 65 & 17 & 4.57 & .65 & 1.22 & .64 & 11.49 & $.99 \mid$ & -.19 & $.23 \mid$ & 82.4 & $82.3 \mid$ & 03 \\
\hline 7 & $\begin{array}{l}63 \\
64\end{array}$ & 17 & $\begin{array}{l}4.57 \\
4.19\end{array}$ & .65 & .86 & $\begin{array}{r}.021 \\
-\quad 52 \mid\end{array}$ & .85 & -.13 & .32 & .23 & 82.4 & 82.3 & 12 \\
\hline 42 & 64 & 17 & 4.19 & .59 & .02 & 05 & . & -.58 & .53 & .251 & 76.5 & 76.4 & 07 \\
\hline 26 & 63 & 17 & 3.86 & .55 & .85 & $\begin{array}{l}-.931 \\
-.56 \mid\end{array}$ & .39 & -1.08 & .12 & .23 & 16.5 & 76.4 & 42 \\
\hline 19 & 62 & 17 & 3.57 & $.53 \mid$ & .76 & & 171 & 0 & . & נרכו & & 67 & \\
\hline 33 & 62 & 17 & 3.57 & .53 & 92 & $\mid$\begin{tabular}{l|}
-1.24 \\
-
\end{tabular} & .71 & -1.21 & .04 & .27 & 82.4 & 67.7 & 19 \\
\hline 21 & 61 & 17 & 3.31 & .51 & .83 & & 11.10 & .49 & .32 & .27 & 82.4 & 67.71 & 33 \\
\hline 32 & 60 & 17 & 3.05 & .50 & .76 & -.991 & .82 & $-.88 \mid$ & .52 & .28 & 76.5 & 64.1 & 21 \\
\hline & & & 2.80 & .50 & & -1.68 & .73 & -1.64 & .65 & .28 & 76.5 & $60.8 \mid$ & 32 \\
\hline & 59 & 17 & 2.80 & .501 & & 4.38 & 11.89 & $3.96 \mid$ & .39 & .28 & 41.2 & 60.11 & 16 \\
\hline & 57 & 17 & 2.28 & $.52 \mid$ & & 3.27 & 11.58 & 2.78 & .09 & .28 & 41.2 & 60.1 & 41 \\
\hline & 57 & 17 & 2.28 & 52 & 1.00 & .09| & .96 & -.08 & .22 & .27 & 58.8 & $66.5 \mid$ & 02 \\
\hline & & 17 & 2.28 & .521 & .91 & -.37 & 11.00 & .10 & .31 & .27 & 82.4 & 66.5 & 13 \\
\hline & & 17 & 201 & .32 & 1.30 & $1.37 \mid$ & |1.36 & $1.35 \mid$ & .49 & $.27 \mid$ & 70.6 & 66.5 & 43 \\
\hline & & & & $\begin{array}{l}.54 \\
.54\end{array}$ & .86 & $-.50 \mid$ & .81 & -.54 & .41 & .27 & 76.5 & 70.6 & 14 \\
\hline $\begin{array}{l}18 \\
25\end{array}$ & 56 & & 2.01 & .54 & .77 & $-.87 \mid$ & .70 & $-.97 \mid$ & .55 & $.27 \mid$ & 76.5 & 70.6 & 18 \\
\hline $\begin{array}{l}25 \\
30\end{array}$ & 56 & 17 & $\begin{array}{l}2.01 \\
2.01\end{array}$ & .541 & 1.46 & $1.62 \mid$ & 1.70 & 1.96 & .26 & $.27 \mid$ & 64.7 & $70.6 \mid$ & 25 \\
\hline $\begin{array}{r}30 \\
4\end{array}$ & 56 & 17 & $\begin{array}{l}2.01 \\
1.71\end{array}$ & .561 & $\begin{array}{l}1.04 \\
1.16\end{array}$ & $.25 \mid$ & |1.17 & $.63 \mid$ & .04 & $.27 \mid$ & 76.5 & 70.61 & 30 \\
\hline $\begin{array}{r}4 \\
28\end{array}$ & $\begin{array}{l}35 \\
55\end{array}$ & 17 & 1.71 & .56 & $\begin{array}{r}1.16 \\
.85\end{array}$ & $\begin{array}{r}.57 \\
-39\end{array}$ & 1.32 & .89 & -.23 & .25 & 70.6 & $75.0 \mid$ & 04 \\
\hline 35 & 55 & 17 & 1.71 & $.56 \mid$ & & -.391 & 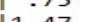 & -.00 & .30 & .231 & 70.0 & 15.01 & 28 \\
\hline 47 & 55 & 17 & 1.71 & .56 & &.$/ 91$ & $1.4 /$ & 1.20 & -.38 & .251 & 10.6 & 75.0 & 35 \\
\hline & & & 1.37 & .60 & & $-1.01 \mid$ & .60 & -1.08 & .63 & .25 & 82.4 & $75.0 \mid$ & 47 \\
\hline & & & & & .68 & $-.78 \mid$ & .58 & $-.93 \mid$ & .53 & .24 & 82.4 & 79.6 & 05 \\
\hline 46 & 54 & 17 & & .601 & .96 & .081 & 11.12 & $.40 \mid$ & -.08 & .241 & 82.4 & $79.6 \mid$ & 09 \\
\hline 38 & 53 & 17 & 1.38 & & .96 & .04 & .91 & $-.04 \mid$ & .06 & .24 & 82.4 & 79.6 & 46 \\
\hline 40 & 53 & 17 & .98 & .65 & 1.64 & $\begin{array}{l}1.25 \\
-.78 \mid\end{array}$ & 1.68 & 1.21 & .05 & .22 & 76.5 & 84.01 & 38 \\
\hline 44 & 53 & 17 & .98 & .65 & .85 & $-.14 \mid$ & .93 & .05 & 89 & 221 & 88.2 & 84.0 & 40 \\
\hline 6 & 52 & 17 & .52 & .701 & .32 & -1.37 & .20 & -1.74 & .55 & .21 & 94.1 & 872 & 44 \\
\hline 1 & 51 & 17 & .00 & $.73 \mid$ & .04 & $-2.77 \mid$ & .03 & $-2.77 \mid$ & .00 & .201 & 100.0 & 88.51 & 01 \\
\hline 10 & 51 & 17 & .00 & $.73 \mid$ & .04 & -2.77 & .03 & -2.77 & .00 & $.20 \mid$ & 100.0 & 88.51 & 10 \\
\hline 22 & 51 & 17 & .00 & $.73 \mid$ & .04 & $-2.77 \mid$ & .03 & -2.77 & .00 & $.20 \mid$ & 100.0 & 88.51 & 22 \\
\hline 24 & 51 & 17 & .00 & .731 & | 3.14 & $2.35 i$ & 13.00 & $2.19 \mid$ & .11 & .201 & 64.7 & $88.5 \mid$ & 24 \\
\hline 27 & 51 & 17 & .00 & .731 & .04 & $-2.77 \mid$ & .03 & -2.77 & .00 & .201 & 100.0 & 88.51 & 27 \\
\hline 31 & 51 & 17 & .00 & .731 & .04 & $-2.77 \mid$ & .03 & -2.77 & .00 & .201 & 100.0 & 88.51 & 31 \\
\hline 17 & 50 & 17 & -.52 & $.70 \mid$ & .43 & -1.01 & .35 & -1.18 & .28 & $.21 \mid$ & 94.1 & 87.21 & 17 \\
\hline 29 & 50 & 17 & -.52 & $.70 \mid$ & 1.62 & $1.08 \mid$ & 1.62 & $1.04 \mid$ & -.21 & $.21 \mid$ & 82.4 & 87.21 & 29 \\
\hline 11 & 49 & 17 & -.98 & $.65 \mid$ & 1.44 & .94 & 1.58 & 1.07 & .36 & $.23 \mid$ & 76.5 & 84.01 & 11 \\
\hline 23 & 49 & 17 & -.98 & $.65 \mid$ & 1.41 & .89 & 1.54 & 1.02 & .42 & $.23 i$ & 76.5 & 84.01 & 23 \\
\hline 34 & 49 & 17 & -.98 & $.65 \mid$ & .65 & $-.63 \mid$ & .61 & $-.65 \mid$ & .33 & $.23 \mid$ & 88.2 & 84.01 & 34 \\
\hline 20 & 46 & 17 & -2.01 & .54 & 1.20 & .79 & 1.19 & $.68 \mid$ & -.12 & .271 & 58.8 & $70.9 \mid$ & 20 \\
\hline $\mathrm{N}$ & 56.8 & 7.0 & 2.08 & .66 & .95 & $-.1 \mid$ & .97 & $-.1 \mid$ & & & 80.2 & 78.51 & \\
\hline . SD & 5.9 & .0 & 2.09 & $.21 \mid$ & .54 & $1.5 \mid$ & .58 & 1.51 & & & 13.3 & $9.4 \mid$ & \\
\hline
\end{tabular}

Figure 7. Person Measure Order table 
From the picture above, it can be seen that all respondents answered the 17 questionnaire responses that were given. In the picture above, the measure column shows the ability of each respondent in logit units. Respondents who have the highest value are 47 respondents, respondent number 15 with measure value $=+7.12$. It can be seen in the infit and outfit value table for 47 respondents who have the highest ability. This is the Maximum measure. For respondents who have the lowest value with measure $=-2.01$, namely respondent number 20 . It can be seen from the data above that several respondents have the same logit value. This means that it shows that the raw score is the same (total score) as well as the ability. To see further which respondents have higher ability, it can be seen from the scalogram. The scalogram can see which respondents have the higher ability even though they have the same logit value. The level of ability here is the response data in agreeing on the questionnaire response items given to the student response to MOOCS as the AR-assisted elearning method used. To find out the aspect of the mismatch of the response with the ideal model as in table 6 person fit order, as in the table below:

Person STATISTICS: MISFIT ORDER

\begin{tabular}{|c|c|c|c|c|c|c|c|c|c|c|c|c|c|}
\hline \multirow{3}{*}{$\begin{array}{l}\text { ENTRY } \\
\text { NUMBER } \\
\end{array}$} & \multirow{2}{*}{$\begin{array}{l}\text { TOTAL } \\
\text { SCORE }\end{array}$} & \multirow{2}{*}{$\begin{array}{l}\text { TOTAL } \\
\text { COUNT }\end{array}$} & \multirow[b]{2}{*}{ MEASURE } & \multirow{2}{*}{$\begin{array}{l}\text { MODELL } \\
\text { S.E. }\end{array}$} & \multicolumn{2}{|c|}{ INFIT } & \multicolumn{2}{|c|}{ OUTFIT } & \multicolumn{4}{|c|}{ |PTMEASUR-AL|EXACT MATCH| } & \multirow{2}{*}{ Person } \\
\hline & & & & & MNSQ & ZSTD| & MNSQ & ZSTD & |CORR. & EXP.I & OBS\% & EXP\%| & \\
\hline & & & & & & -- & & -- & & -- & & . & \\
\hline 24 & 51 & 17 & .00 & $.73 \mid$ & | 3.14 & 2.35 & $\mid 3.00$ & 2.19 & |A. .11 & $.20 \mid$ & 64.7 & 88.5 & 24 \\
\hline 16 & 59 & 17 & 2.80 & $.50 \mid$ & 1.84 & 4.38 & 1.89 & 3.96 & B .39 & .28 & 41.2 & 60.1 & 16 \\
\hline 25 & 56 & 17 & 2.01 & $.54 \mid$ & |1.46 & $1.62 \mid$ & |1.70 & 1.96 & |C .26 & $.27 \mid$ & 64.7 & $70.6 \mid$ & 25 \\
\hline 38 & 53 & 17 & .98 & $.65 \mid$ & 1.64 & 1.25 & 1.68 & $1.21 \mid$ & D. .05 & .22 & 76.5 & 84.0 & 38 \\
\hline 29 & 50 & 17 & -.52 & $.70 \mid$ & 1.62 & 1.08 & 1.62 & 1.04 & $\mid E-.21$ & $.21 \mid$ & 82.4 & 87.21 & 29 \\
\hline 41 & 59 & 17 & 2.80 & $.50 \mid$ & 1.59 & 3.27 & 1.58 & 2.78 & |F .09 & .28 & 41.2 & $60.1 \mid$ & 41 \\
\hline 11 & 49 & 17 & -.98 & $.65 \mid$ & |1.44 & $.94 \mid$ & 1.58 & $1.07 \mid$ & |G.36 & $.23 \mid$ & 76.5 & 84.0 & 11 \\
\hline 37 & 66 & 17 & 5.07 & .77| & |1.15 & .45 & |1.55 & $.90 \mid$ & |H-.15 & .20 & 88.2 & $88.2 \mid$ & 37 \\
\hline 23 & 49 & 17 & -.98 & $.65 \mid$ & |1.41 & $.89 \mid$ & |1.54 & 1.02 & |I .42 & $.23 \mid$ & 76.5 & 84.0 & 23 \\
\hline 3 & 65 & 17 & 4.57 & $.65 \mid$ & 1.22 & $.64 \mid$ & | 1.49 & .99| & |J-.19 & $.23 \mid$ & 82.4 & $82.3 \mid$ & 03 \\
\hline 35 & 55 & 17 & 1.71 & $.56 \mid$ & |1.24 & $.79 \mid$ & |1.47 & 1.20 & |K-.38 & .25 & 70.6 & 75.0 & 35 \\
\hline 43 & 57 & 17 & 2.28 & $.52 \mid$ & 1.30 & $1.37 \mid$ & |1.36 & 1.35 & |L .49 & .27 & 70.6 & 66.51 & 43 \\
\hline 4 & 55 & 17 & 1.71 & $.56 \mid$ & 1.16 & $.57 \mid$ & |1.32 & $.89 \mid$ & |M-.23 & $.25 \mid$ & 70.6 & 75.0 & 04 \\
\hline 36 & 67 & 17 & 5.85 & $1.04 \mid$ & |1.07 & $.38 \mid$ & |1.31 & .62 & $\mid N-.05$ & .15 & 94.1 & 94.1 & 36 \\
\hline 39 & 66 & 17 & 5.07 & .77| & |1.14 & $.43 \mid$ & |1.27 & .58 & $10-.07$ & .20 & 88.2 & $88.2 \mid$ & 39 \\
\hline 20 & 46 & 17 & -2.01 & $.54 \mid$ & 1.20 & $.79 \mid$ & 1.19 & $.68 \mid$ & |P-.12 & $.27 \mid$ & 58.8 & $70.9 \mid$ & 20 \\
\hline 30 & 56 & 17 & 2.01 & .54 & 1.04 & $.25 \mid$ & |1.17 & $.63 \mid$ & lQ .04 & $.27 \mid$ & 76.5 & $70.6 \mid$ & 30 \\
\hline 9 & 54 & 17 & 1.37 & $.60 \mid$ & .98 & .08 & |1.12 & .40 & |R-.08 & $.24 \mid$ & 82.4 & $79.6 \mid$ & 09 \\
\hline 33 & 62 & 17 & 3.57 & $.53 \mid$ & .92 & $-.34 \mid$ & 11.10 & .49 & |S.32 & $.27 \mid$ & 82.4 & $67.7 \mid$ & 33 \\
\hline 45 & 67 & 17 & 5.85 & 1.04 & |1.03 & $.33 \mid$ & .89 & .26 & |T .12 & .15 & 94.1 & $94.1 \mid$ & 45 \\
\hline 2 & 57 & 17 & 2.28 & $.52 \mid$ & 1.00 & $.09 \mid$ & .96 & -.08 & |U .22 & $.27 \mid$ & 58.8 & $66.5 \mid$ & 02 \\
\hline 13 & 57 & 17 & 2.28 & $.52 \mid$ & .91 & $-.37 \mid$ & 1.00 & .10 & IV .31 & $.27 \mid$ & 82.4 & $66.5 \mid$ & 13 \\
\hline 12 & 65 & 17 & 4.57 & .65 & .96 & .02 & .85 & -.13 & |W. .32 & $.23 \mid$ & 82.4 & $82.3 \mid$ & 12 \\
\hline 46 & 54 & 17 & 1.37 & $.60 \mid$ & .96 & .04 & .91 & -.04 & Iw .06 & $.24 \mid$ & 82.4 & $79.6 \mid$ & 46 \\
\hline 44 & 53 & 17 & .98 & $.65 \mid$ & .85 & -.14 & .93 & .05 & |v-.09 & .22 & 88.2 & $84.0 \mid$ & 44 \\
\hline 14 & 56 & 17 & 2.01 & $.54 \mid$ & .86 & -.50 & .81 & -.54 & |u .41 & $.27 \mid$ & 76.5 & $70.6 \mid$ & 14 \\
\hline 26 & 63 & 17 & 3.86 & $.55 \mid$ & .85 & $-.56 \mid$ & .79 & $-.62 \mid$ & it . .50 & $.26 \mid$ & 82.4 & $71.8 \mid$ & 26 \\
\hline 28 & 55 & 17 & 1.71 & $.56 \mid$ & .85 & -.39 & .75 & -.60 & Is . .38 & .25 & 70.6 & $75.0 \mid$ & 28 \\
\hline 21 & 61 & 17 & 3.31 & $.51 \mid$ & .83 & $-.99 \mid$ & .82 & $-.88 \mid$ & |r. .52 & $.28 \mid$ & 76.5 & 64.1| & 21 \\
\hline 7 & 64 & 17 & 4.19 & $.59 \mid$ & .82 & $-.52 \mid$ & .74 & $-.58 \mid$ & |q. .53 & $.25 \mid$ & 76.5 & $76.4 \mid$ & 07 \\
\hline 8 & 66 & 17 & 97 & |77| & .80 & $-.20 \mid$ & .50 & $-.63 \mid$ & lp . .57 & $.20 \mid$ & 88.2 & 88.21 & 08 \\
\hline 18 & 56 & 17 & 2.01 & $.54 \mid$ & .77 & $-.87 \mid$ & .70 & $-.97 \mid$ & |o . .55 & $.27 \mid$ & 76.5 & $70.6 \mid$ & 18 \\
\hline 19 & 62 & 17 & 3.57 & $.53 \mid$ & .76 & $-1.24 \mid$ & .71 & -1.21 & In $\quad .64$ & $.27 \mid$ & 82.4 & $67.7 \mid$ & 19 \\
\hline 32 & 60 & 17 & 3.05 & $.50 \mid$ & .76 & -1.68 & .73 & -1.64 & Im . .65 & .28 & 76.5 & $60.8 \mid$ & 32 \\
\hline 42 & 64 & 17 & 4.19 & $.59 \mid$ & .70 & $-.95 \mid$ & | .59 & -1.08 & |1 .72 & .25 & 76.5 & $76.4 \mid$ & 42 \\
\hline 5 & 54 & 17 & 1.37 & $.60 \mid$ & .68 & -.78 & | .58 & $-.93 \mid$ & |k . .53 & .24 & 82.4 & $79.6 \mid$ & 05 \\
\hline 47 & 55 & 17 & 1.71 & $.56 \mid$ & .68 & -1.01 & .60 & -1.08 & Ij . .63 & .25 & 82.4 & $75.0 \mid$ & 47 \\
\hline 34 & 49 & 17 & -.98 & $.65 \mid$ & .65 & $-.63 \mid$ & .61 & $-.65 \mid$ & |i .33 & $.23 \mid$ & 88.2 & 84.01 & 34 \\
\hline 40 & 53 & 17 & .98 & $.65 \mid$ & .60 & $-.78 \mid$ & | . .52 & $-.88 \mid$ & |h .44 & $.22 \mid$ & 88.2 & 84.0 & 40 \\
\hline 17 & 50 & 17 & -.52 & $.70 \mid$ & .43 & $-1.01 \mid$ & | .35 & -1.18 & $\lg .28$ & .21| & 94.1 & $87.2 \mid$ & 17 \\
\hline 6 & 52 & 17 & .52 & $.70 \mid$ & .32 & $-1.37 \mid$ & .20 & -1.74 & If. .55 & $.21 \mid$ & 94.1 & 87.21 & 06 \\
\hline 1 & 51 & 17 & .00 & $.73 \mid$ & .04 & -2.77 & .03 & $-2.77 \mid$ & le .00 & .20 & 100.0 & 88.51 & 01 \\
\hline 10 & 51 & 17 & .00 & .731 & .04 & $-2.77 \mid$ & .03 & -2.77 & Id . .00 & .20 & 100.0 & $88.5 \mid$ & 10 \\
\hline 22 & 51 & 17 & .00 & .73| & .04 & $-2.77 \mid$ & .03 & $-2.77 \mid$ & |c . .00 & $.20 \mid$ & 100.0 & $88.5 \mid$ & 22 \\
\hline 27 & 51 & 17 & .00 & .73| & .04 & $-2.77 \mid$ & .03 & $-2.77 \mid$ & lb .00 & .20 & 100.0 & 88.5 & 27 \\
\hline 31 & 51 & 17 & .00 & $.73 \mid$ & .04 & $-2.77 \mid$ & | .03 & $-2.77 \mid$ & la .00 & $.20 \mid$ & 100.0 & 88.51 & 31 \\
\hline MLAIV & 56.8 & 17.0 & 2.08 & $.66 \mid$ & .95 & -.1 & .97 & -.1 & & & 80.2 & $78.5 \mid$ & \\
\hline P.SD & 5.9 & .0 & 2.09 & $.21 \mid$ & | .54 & $1.5 \mid$ & | .58 & $1.5 \mid$ & & & 13.3 & $9.4 \mid$ & \\
\hline
\end{tabular}

\section{Figure 8. Misfit Person Table}

In the table above, it can be seen that the most petite fit is the respondent with codes 24 and 16. This indicates a tendency for an inconsistent pattern among the three respondents in terms of 
answering these questions. And it can be seen that all respondents have at least 1 predetermined limit criteria value as in the Person Misfit Table. And to see complete suitability can be seen in the following Guttmann matrix

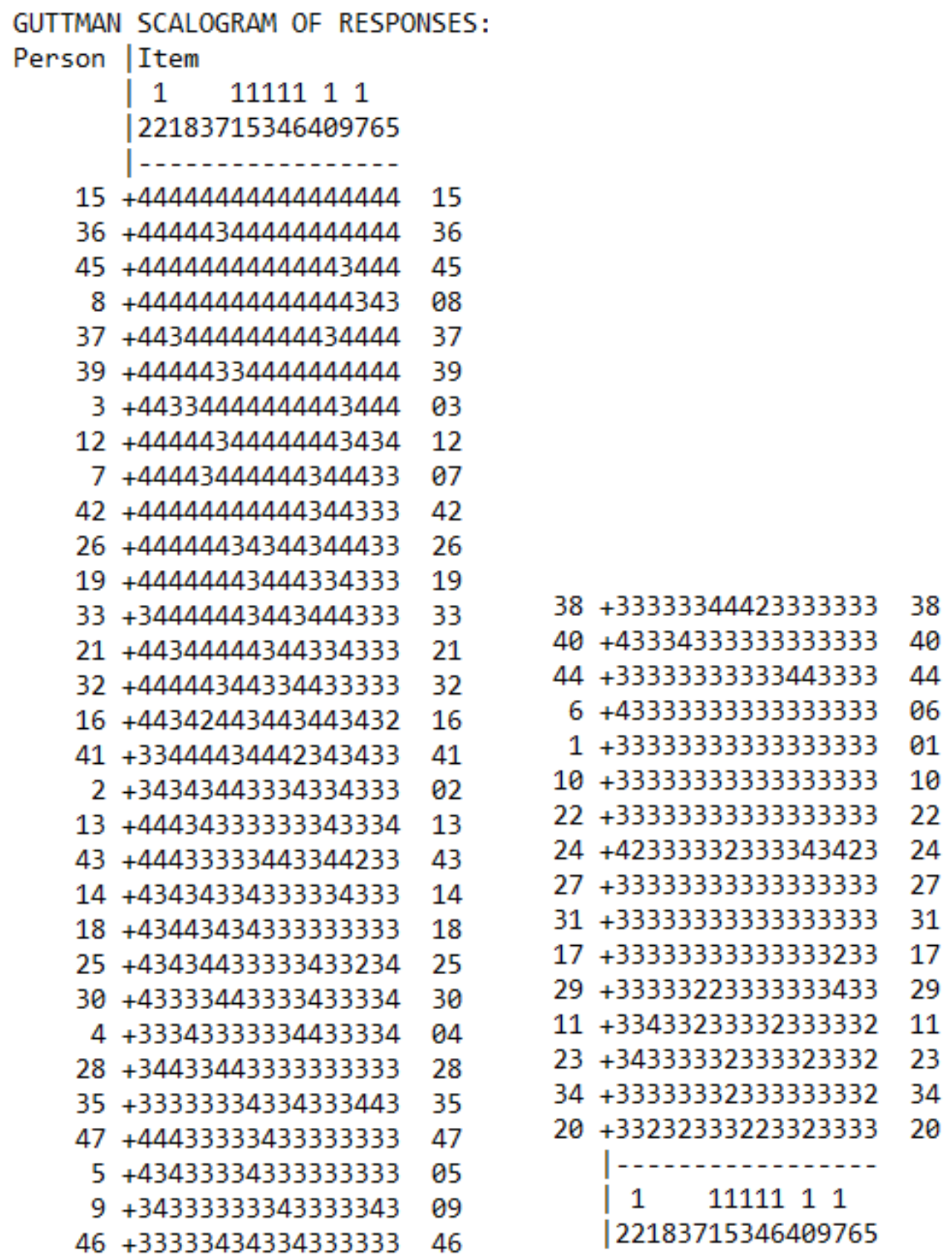

\section{Figure 9. Table Scalogram Guttman}

From the table scalogram Guttman we can see the pattern of respondents' answers. It appears that there are similarities in answers between 47 respondents who have the highest ability, one of which is respondent no. $01,10,22,27$, and 31, which have the same answer pattern. There are not many similarities in the answers of respondents at this time.

From the similarity of the respondent's answer pattern, this can indicate that the respondents are cooperating or cheating in filling out the questionnaire items so that it is necessary to re-evaluate. It can be seen that the scalogram has a response pattern that is irregular/ inconsistent with the answer. This also shows that at certain points, it tends to agree with the statement (getting a high/difficult item score) while on other items, it tends to reject it (getting item scores low/ easy). 
This may be because respondents at that time lacked the motivation to respond to the scale. This low motivation causes them to give reckless responses. The implication is that their responses are varied and inconsistent, depending on their mood when responding to grain (Risdianto et al., 2020).

\section{CONCLUSION}

The analysis has been carried out based on the questionnaire analysis of the student response to the questionnaire response items implementation of the application of the Blended Learning model based on MOOCs assisted by augmented reality (BMA). It can be concluded that the implementation of this BMA model received a very good response with the majority of respondents agreeing to all the questionnaire items given. This is supported by a valid and reliable data questionnaire. In addition, it is strengthened by the quality of the student response questionnaire used very well so that it can be used to determine the response to the implementation of the BMA model in the AR-assisted MOOCS system used. MOOCs are the learning trend of the future.

\section{REFERENCE}

Busri, E., Zulirfan, Z., \& Fakhruddin, F. (2019). The Development of MOOC Media to Increase Recall Memory Skill on Physics at Vocational High School. Journal of Physics: Conference Series, 1(1), 1-4. https://doi.org/10.1088/1742-6596/1351/1/012017

Emigawaty. (2017). Perancangan Arsitektur Dan Purwarupa Model Pembelajaran Massive Open Online Course (Moocs) Di Perguruan Tinggi Menggunakan Layanan Mobile. Jurnal Ilmiah DASI, 18(1), 25-30.

Fandianta, Sanjaya, G. Y., \& Widyandana. (2013). Meningkatkan Pengetahuan Mahasiswa dengan Memberikan Fleksibilitas Belajar Mengajar melalui Metode Blended Learning. Jurnal Pendidikan Kedokteran Indonesia, 2(2), 1-8.

Fathurrochman, I., Danim, S., Anwar AB, S., \& Kurniah, N. (2021). The School Principals' Role in Education Management at the Regional Level: An Analysis of Educational Policy in the Industrial Revolution 4.o. Advances in Social Science, Education and Humanities Research, $532,237-242$.

Husna, J. (2019). Implementasi MOOCs di Pendidikan Ilmu Perpustakaan dan Informasi (Sebuah Peluang dan Tantangan di Indonesia). Anuva: Jurnal Kajian Budaya, Perpustakaan, Dan Informasi, 3(3), 247-256.

Ismail, M. E., Hashim, S., Ismail, I. M., Ismail, A., Daud, K. A. M., \& Khairudin, M. (2018). Penggunaan Massive Open Online Course (Mooc) Dalam Kalangan Pelajar Vokasional. Journal of Nusantara Studies, 3(1), 30-41.

Khoiroh, N., Munoto, \& Anifah, L. (2017). Pengaruh model pembelajaran blended learning dan motivasi belajar terhadap hasil belajar siswa. jurnal penelitian ilmu pendidikan, 1O(2), 97-110.

Nuryanti, S., Masykuri, M., \& Susilowati, E. (2018). Analisis Iteman dan model Rasch pada pengembangan instrumen kemampuan berpikir kritis peserta didik sekolah menengah kejuruan. Jurnal Inovasi Pendidikan, 4(2), 224-233.

Oktaria, S. D., Budiningsih, A., \& Risdianto, E. (2018). Model Blended Learning Berbasis Moodle. In Halaman Moeka Publishing.

Pragestu, S., Sujiani, H., \& Negara, A. B. P. (2015). Implementasi Augmented Reality dengan Memanfaatkan GPS Based Tracking pada Sistem. Jurnal Edukasi Dan Penelitian Informatika (JEPIN), 1(2), 122-127.

Praherdhiono, H., Adi, E. P., \& Prihatmoko, Y. (2018). Konstruksi Demokrasi Belajar Berbasis Kehidupan Pada Implementasi Lms Dan Mooc. Edcomtech, 3(1), 21-28.

Prayitno, E., \& Masduki, L. R. (2017). Pengembangan Media Blended Learning Dengan Model Flipped Classroom Pada Mata Kuliah Pendidikan Matematika Ii. JIPMat, 1(2), 121-126. https://doi.org/10.26877/jipmat.v1i2.1238

Priono, A. I., Purnawan, P., \& Komaro, M. (2018). Pengaruh Penerapan Model Pembelajaran Blended Learning Terhadap Hasil Belajar Menggambar 2 Dimensi Menggunakan Computer Aided Design. Journal of Mechanical Engineering Education, 5(2), 129-140. https://doi.org/10.17509/jmee.v5i2.15179

Putrawangsa, S., \& Hasanah, U. (2018). Integrasi Teknologi Digital Dalam Pembelajaran Di Era Industri 4.o Kajian dari Perspektif Pembelajaran Matematika. Jurnal Tatsqif, 16(1), 42-54. 
https://doi.org/10.20414/jtq.v16i1.203

Rafiq, K. R. M., Hashim, H., Yunus, M. M., \& Pazilah, F. N. (2019). Developing a MOOC for communicative english: A battle of instructional designs. International Journal of Innovation, Creativity and Change, $7(7), 29-39$.

Risdianto, E. (2019). Development of Blended Learning Based on Web and Augmented Reality. 1st International Conference on Educational Sciences and Teacher Profession (ICETeP 2018), 295, 144-147.

Risdianto, E., Darmawan, A., Kristiawan, M., Wachidi, \& Riyanto. (2020). Rasch model analysis on the feasibility test of basic physics ii practical guide using augmented reality. ARPN Journal of Engineering and Applied Sciences, 15(4), 482-490.

Risdianto, E., Syarkowi, A., \& Jumiarni, D. (2021). Kajian dan Riset Dalam Teknologi Pembelajaran Analisis Data Respon Mahasiswa Terhadap Matakuliah Ilmu Lingkungan Menggunakan. 8(1), 47-57. https://doi.org/10.17977/umo31v8i12021po47

Siahaan, A. D., Medriati, R., \& Risdianto, E. (2019). Pengembangan Penuntun Praktikum Fisika Dasar Ii Menggunakan Teknologi Augmented Reality Pada Materi Rangkaian Listrik Dan Optik Geometris. Jurnal Kumparan Fisika, 2(2), 91-98. https://doi.org/10.33369/jkf.2.2.91-98

Sudarsana, I. K. (2018). Optimalisasi Penggunaan Teknologi Dalam Implementasi Kurikulum Di Sekolah (Perspektif Teori Konstruktivisme). Jurnal Ilmu Pendidikan, 1(1), 8-15.

Sumintono, B. dan W. (2015). Aplikasi Permodelan Rasch pada Assessment Pendidikan. (B. Trim (ed.)). Trim Komunikata.

Suyasa, P. W. A., Divayana, D. G. H., \& Adiarta, A. (2017). Pemberdayaan Teknologi Open Source Dalam Pembuatan Modul Digital Bagi Para Dosen di Lingkungan STIKES Buleleng. Jurnal Widya Laksana, 6(2), 120-129.

Untary, H., Risdianto, E., \& Kusen. (2020). Analisis Data Penelitian dengan Model Rasch dan Winstep. Halaman Moeka.

Usman, U. (2018). Komunikasi Pendidikan Berbasis Blended Learning Dalam Membentuk Kemandirian Belajar. Jurnal Jurnalisa, 4(1), 136-150. https://doi.org/10.24252/jurnalisa.v4i1.5626

Wahyuningsih, S. A. (2020). Penggunaan Model Rasch Untuk Analisis Instrumen the Use of Rasch Model for Analyzing Test. Jurnal Pendidikan Matematika, 3(1), 45-50.

Wardani, D. N., Toenlioe, A. J. E., \& Wedi, A. (2018). Daya Tarik Pembelajaran Di Era 21 Dengan Blended Learning. Jurnal Kajian Teknologi Pendidikan (JKTP), 1(1), 13-18.

Yodha, S., Abidin, Z., \& Adi, E. (2019). Persepsi Mahasiswa Terhadap Pelaksanaan E-Learning Dalam Mata Kuliah Manajemen Sistem Informasi Mahasiswa Jurusan Teknologi Pendidikan Universitas Negeri Malang. Jurnal Kajian Teknologi Pendidikan, 2(3), 181-187. https://doi.org/10.17977/umo38v2i32019p181 